\title{
Blood transport and genomic effects of olive oil components
}

\author{
By Yolanda M. Pacheco, Beatriz Bermúdez, Sergio López, Rocío Abia \\ and Francisco J.G. Muriana*
}

\author{
Cellular and Molecular Nutrition, Instituto de la Grasa, \\ Consejo Superior de Investigaciones Científicas, Seville, Spain \\ "Corresponding author: Dr. Francisco J.G. Muriana. Tel: +34 954611550 \\ Email: muriana@ig.csic.es
}

\section{CONTENTS}

1. INTRODUCTION

2. SECRETION OF LIPOPROTEINS BY THE ENTEROCYTE

3. INFLUENCE OF OLIVE OIL ON POSTPRANDIAL LIPOPROTEINS TRANSPORT

4. INFLUENCE OF OLIVE OIL ON POSTPRANDIAL LIPOPROTEINS CLEARANCE

5. ROLE OF APOLIPOPROTEINS AND RECEPTORS ON MECHANISMS INVOLVED IN POSTPRANDIAL LIPOPROTEINS CLEARANCE

6. SECRETION OF LIPOPROTEINS BY THE LIVER

7. METABOLIC EFFECTS OF OLIVE OIL

7.1. Non-genomic effects of olive oil

7.2. Genomic effects of olive oil

7.2.1. NF-kB

7.2.2. C-Myc

7.2.3. AP-1

7.2.4. Nuclear receptors

8. METABOLISM AND EXCRETION OF OLIVE OIL MINOR COMPOUNDS

ACKNOWLEDGMENTS

REFERENCES

\section{RESUMEN}

Transporte en sangre y efectos genómicos de los componentes del aceite de oliva.

Estudios epidemiológicos asocian el consumo de una dieta rica en aceite de oliva (virgen extra) con una baja incidencia de enfermedades crónicas, como las enfermedades cardiovasculares y el cáncer. Una concentración elevada de triglicéridos en plasma, tanto en ayunas como durante el metabolismo postprandial, está implicada en la patogénesis cardiovascular. Se ha demostrado que el aceite de oliva contribuye a modular los procesos metabólicos relativos a la secreción y al transporte de triglicéridos. Con respecto a otros aceites comestibles, el aceite de oliva genera lipoproteínas intestinales ricas en triglicéridos que se metabolizan con rapidez. En este contexto, se produce un aflujo masivo de lipoproteínas nacientes y remanentes, así como de metabolitos lipídicos y componentes liposolubles, que interaccionan con células hepáticas y de tejidos extra-hepáticos. La respuesta celular a la dieta implica multitud de productos génicos, incluyendo proteínas asociadas a la síntesis de lípidos, oxidación y diferenciación celular. Se conoce el efecto beneficioso de los ácidos grasos y otros componentes menores en la regulación transcripcional de una gran variedad de genes. En esta revisión se reafirma la importancia de una dieta rica en aceite de oliva virgen extra en la prevención de las enfermedades cardiovasculares y otras.
PALABRAS-CLAVE: Aceite de oliva: Ácidos grasos monoinsaturados; Compuestos menores; Secreción intestinal; Transporte de lipoproteínas; Respuesta celular; Genes; Dieta Mediterránea.

\section{SUMMARY}

Blood transport and genomic effects of olive oil components.

Epidemiological studies suggest that consuming diets rich in (extra virgin) olive oil is associated with a low incidence of chronic diseases, including cardiovascular disease and cancer. Recent evidence has emerged which implicates raised concentrations of plasma triglycerides in the pathogenesis of coronary artery disease (CAD). It has been demonstrated that olive oil contributes to modulate metabolic processes related to secretion and transport of triglycerides. Intestinal triglyceride-rich lipoproteins from olive oil are very efficiently cleared during postprandial metabolism compared to other oils. Then, there is a massive interaction of nascent and remnant triglyceride-rich lipoproteins, as well as lipid metabolites and fat-soluble components, with hepatic and non-hepatic tissues. A diet-related response involves a multitude of gene products, including proteins implicated in lipid synthesis, oxidation and cell differentiation. Particularly, it has been reported a health beneficial effect of several components from (extra virgin) olive oil (fatty acids and minor compounds), which are functioning as regulators of gene transcription. This review reaffirm that a diet rich in extra virgin olive oil is of vital importance in the prevention of cardiovascular and other diseases.

KEY-WORDS: Olive oil; Monounsaturated fatty acids; Minor compounds; Intestinal secretion; Lipoproteins transport Cellular response; Genes; Mediterranean diet.

\section{INTRODUCTION}

Recent evidence has emerged which implicates raised concentrations of plasma triglycerides in the pathogenesis of coronary artery disease (CAD). Exaggerated triglyceride responses to standard fat-containing meals have been shown in subjects with CAD and in offspring with a parental history of premature CAD. The lower rate of CVD in Southern Europe suggests a potential role of the traditional Mediterranean diet in the prevention of CVD. Zampelas et al. (1998) have previously shown no 
difference in postprandial triglyceride response to meals of varying monounsaturated (MUFA) and saturated (SFA) fatty acid content in Northern European men. Later studies they set out to determine whether the same response was observed in Southern European men whose habitual background diet was high in MUFA. Both populations showed similar lipemic responses when meals of varying MUFA and SFA content were fed, but they unexpectedly observed very different postprandial patterns of triglyceride response in the two European populations.

The Mediterranean diet has become a cultural model for dietary improvement. It is characterised by the use of olive oil as the major culinary fat, which is rich in MUFA. In addition, extra virgin olive oil contains a number of phenolic compounds, which via their antioxidant and other potent biological activities could partially account for the observed healthful effects of the traditional Mediterranean Diet.

Traditional Mediterranean Diet is constituted, mainly, plenty of fresh vegetables, fruit, grains and (extra virgin) olive oil with moderate consumption of wine (mainly red wine) and dairy products (mainly cheese). However, there is considerable debate about the nutrients responsible for health effects of a diet. The low SFA/high MUFA content has received considerable attention. The epidemiological evidence of a lower incidence of $\mathrm{CHD}$ in the Mediterranean area also led to the hypothesis of a protective effect of some (extra virgin) olive oil phenolics with respect to chemically induced oxidation of human plasma low-density lipoproteins (LDL), one of steps in the initiation of atherosclerosis (Steinberg et al., 1989). In both cases, fatty acids (as triglycerides, whose fatty acid composition partially depends on the olive oil fatty acid composition) and minor compounds (in free or conjugated forms) have to be transported in blood and to reach hepatic and extra-hepatic systems.

\section{SECRETION OF LIPOPROTEINS BY THE ENTEROCYTE}

The function of chylomicron (CM) and very-low density lipoproteins (VLDL) is to pack the absorbed dietary lipids and fat-soluble components, stabilising

Table 1

Characteristics of intestinal lipoproteins: chylomicrons and very-low density lipoproteins (VLDL) (adapted from Mu and Hoy, 2004)

\begin{tabular}{|c|c|c|}
\hline & Chylomicrons & VLDL \\
\hline Sources & Intestine only & Both intestine and liver \\
\hline Density & $<0.95 \mathrm{~g} / \mathrm{mL}$ & $0.95-1.006 \mathrm{~g} / \mathrm{mL}$ \\
\hline Sdverdberg floation (Sf) & $>400$ & $20-400$ \\
\hline Size & $80-500 \mathrm{~nm}$ & $30-80 \mathrm{~nm}$ \\
\hline Approximate weight (KD) & $50-1000 \times 10^{3}$ & $10-80 \times 10^{3}$ \\
\hline Total lipids & $97-98 \%$ of particle mass & $90 \%$ of particle mass \\
\hline Triglycerides & $\approx 95 \%$ & $\approx 40 \%$ \\
\hline Cholesterol & $\approx 1 \%$ & $\approx 15 \%$ \\
\hline Phospholipids & $\approx 4 \%$ & $\approx 15 \%$ \\
\hline Total protein & $2 \%$ of particle mass & $10 \%$ of particle mass \\
\hline $\begin{array}{l}\text { Major apolipoprotein } \\
\text { components }\end{array}$ & B-48, A-I, A-IV, A-II & $\begin{array}{l}\text { Probably similar to } \\
\text { chylomicrons } \\
\text { (B-100 instead B-48) }\end{array}$ \\
\hline $\begin{array}{l}\text { Minor apolipoprotein } \\
\text { components }\end{array}$ & $\begin{array}{l}\text { C and E (both acquired } \\
\text { through interaction with } \\
\text { other plasma lipoproteins) }\end{array}$ & Same as chylomicrons \\
\hline
\end{tabular}


them for transport in the aqueous plasma environment. Although plasma VLDL are mainly synthesized in the liver, there is incoming evidence that fasting intestine also produces these particles, which do not mix readily in individual Golgi vesicles (Mu and Hoy, 2004). Characteristics of these lipoproteins are detailed in Table 1.

Briefly, triglyceride-rich lipoproteins are spherical particles synthesised by intestinal epithelial cells (Luchoomun and Hussain, 1999), being CM higher $(100 \mathrm{~nm})$ than VLDL $(25-80 \mathrm{~nm})$. Another classification attends to the Svedberg flotation $\left(S_{f}\right)$ rate, which defines $\mathrm{CM}$ as those lipoproteins that exceed $400 \mathrm{~S}_{f}$ and VLDL as those with $S_{f}$ rate of 20-400. The major lipid components are triglycerides, cholesterol esters, free cholesterol and phospholipids. Attending to their distribution in the CM particle, amphipathic molecules form a monolayer that stabilises the lipid core that also contains dietary fat-soluble components. VLDL differ from CM in their density, size, lipid and protein content and composition.

Studies by Luchoomun and Hussain (1999) have shown that in the distribution of lipids in the intestine-assembled lipoproteins, triglyceride-rich lipoproteins contain higher amounts of preformed phospholipids compared with nascent phospholipids. However, VLDL contain similar amounts of preformed and nascent triglycerides, whereas CM rather contain higher amounts of nascent triglycerides. This is why the fatty acid composition of triglycerides, but not of phospholipids, reflects the composition of dietary triglycerides in $\mathrm{CM}$.

Apolipoproteins constitute the protein fraction in lipoproteins and play a major role in their metabolism. Triglyceride-rich lipoproteins contain several different apolipoproteins, including apo B-48, apo B-100, apo Al, apo AIV, apo AII, apo C and apo E (the two last ones are acquired later) (Table 1). There are differences in the relative content of apolipoproteins between CM and intestinal VLDL. For instance, apo A-IV comprises about $40 \%$ of intestinal VLDL, but only $10 \%$ of apo A-IV is present in CM. Human enterocytes have the potential to secrete both apo B-48 and apo B-100, which differ in apoB mRNA post-transcriptional processes. Two approaches have been described to explain the production of apoB and apoB-containing lipoproteins. The first one involves the introduction of a unique RNA editing enzyme, the apoB mRNA editing enzyme catalytic polypeptide-1 (apobec-1) that gives a stop codon at codon 2153, resulting in synthesis of a protein which is $48 \%$ of the apo B-100 molecule. The second one relates the assembly and intracellular sorting of apoB-containing lipoproteins and the inhibition of lipid addition to apo B-100 (Innerarity et al., 1996). Apolipoproteins $B$ have also a critical role in the assembly of triglyceride-rich lipoproteins, because apo B-48 and apo B-100 bind differently to LDL receptor (van Greevenbroek and de Bruin, 1998a). A general belief is that apo $B-100$ is exclusive of VLDL, as liver VLDL can only content apo B-100, but the truth is that large CM can contain both apo B-48 and apo B-100 (Luchoomun and Hussain, 1999).

It has been described that pathways for triglyceride synthesis influence the amount of apo $B$ in the secreted triglyceride-rich lipoproteins (Mu and Hoy, 2004). The "triglyceride synthetase" pathway (predominant in the feeding state) produces larger particles with lesser apolipoprotein content, whereas the phosphatidic acid pathway (predominant in the fasting state) produces smaller particles with twice as much apolipoprotein per gram of fat than the former pathway.

\section{INFLUENCE OF OLIVE OIL ON POSTPRANDIAL LIPOPROTEINS TRANSPORT}

Intestinal chylomicrons (CM) and VLDL transport dietary fat but also triglycerides from endogenous sources (Shiau et al., 1985). Endogenous triglycerides come in part from circulating fatty acids and remnant $\mathrm{CM}$ taken up by enterocytes, and do not readily enter in the $\mathrm{CM}$ secretory pathway. That is why the fatty acid composition of $\mathrm{CM}$ triglycerides closely reflects that of dietary triglycerides (Mu and Hoy, 2004).

The composition and structures of dietary triglycerides determine intestinal absorption and lipoprotein secretion (Aoe et al., 1997). After stomach infusion of 1,3-dioleoyl-2-palmitoyl glycerol (OPO) and 1,2-dioleoyl-3-palmitoyl glycerol (OOP), the mean diameter of CM containing OPO are larger than those carrying OOP. OPO is better absorbed and transported than OOP. Other parameters related to composition of dietary triglycerides are the size and number of postprandial lipoproteins. The unsaturation degree of fatty acids tends to increase the size of $\mathrm{CM}$ (Sakr et al., 1997). Even, the configuration of double bonds can condition the size of postprandial lipoproteins (van Greevenbroek et al., 1998b).

Particularly, olive oil increases the number of $\mathrm{CM}$ compared with other oils, including saturated, $n-6$ and $n-3$ polyunsaturated-enriched oils (Jackson et al., 2002). Possible mechanisms could imply the modulation in the enterocytes of the activity or expression of microsomal triglyceride transfer protein (MTP), or mRNA editing enzyme that involves the co-translational enrichment in lipids of apo B and further lipidation of the primordial particle along the secretory pathway (van Greevenbroek et al., 1998c). Therefore, olive oil could be enabling the stabilization of the nascent CM particles with smaller lipid droplets by affecting the enzymes involved in the lipoprotein assembly. Indeed, unsaturated fatty acids, especially oleic acid, are more efficiently incorporated into lipoproteins by MTP (van Greevenbroek et al., 1996). 
The size and number of $\mathrm{CM}$ influence their fate and rate of clearance. Large CM are preferentially hydrolyzed by lipoprotein lipase (LPL), which produces remaining cholesterol ester-rich particles (remnant CM) after the removal of $70-90 \%$ of triglycerides. Remnant particles interact with hepatic lipase $(\mathrm{HL})$ that further hydrolyses triglycerides and phospholipids, preparing remnant to be up taken by liver receptor-mediated process (Sultan et al., 1990). It has been suggested that CM from olive oil are poorly hydrolysed by LPL due to the greater particle number, but rapidly removed by $\mathrm{HL}$ (Jackson et al., 2002). Certainly, olive oil contributes to modulate metabolic processes related to secretion and transport of triglycerides.

\section{INFLUENCE OF OLIVE OIL ON POSTPRANDIAL LIPOPROTEINS CLEARANCE}

Endothelial cells by the heparan sulphate proteoglycan-dependent LPL and the endothelial lipase (EL) initially participate in the clearance of postprandial triglyceride-rich lipoproteins. LPL (with mainly acylglycerol hydrolase activity) and EL (with mainly phospholipase activity) co-ordinately remodel the surface of CM. This step is essential for accessing the $\mathrm{CM}$ triglyceride core. The largest $\mathrm{CM}$ have the highest affinity for LPL (Xiang et al., 1999). The action of the LPL produces free fatty acids (FFA) and monoglycerides (MG), turning CM into remnant lipoproteins. Moreover, the amount of soluble LPL is proportional to the amount of triglycerides in plasma (Heeren et al., 2002). It is interesting to note that CM with PUFA have faster lipolysis than CM with SFA (Chung et al., 1998). The activity of pre-heparin LPL is sensitive to dietary fatty acids, enhancing in the presence of $n$-3 PUFA (Park et al., 2003). In addition, EL bound to postprandial lipoproteins facilitates the hepatic clearance independently of its catalytic function (Heeren et al., 2002).

Olive oil increases the amount of postprandially nascent and remnant triglyceride-rich lipoproteins compared with other fats, including safflower oil and milk fat (Higashi et al., 1997). Similar findings have been described by Mekki et al. (2002), who found that a meal rich in butter has lower postprandial lipemic response than sunflower and olive oils. The time to reach the triglyceride postprandial peak is also higher with olive oil (Jackson et al., 2002). CM-triglycerides from olive oil are very efficiently cleared during postprandial metabolism compared to other MUFA-containing oils, which depends on the distribution of fatty acids into triglyceride and phospholipids molecules (Abia et al., 2003). Oleic acid $(18: 1 n-9)$ is the main fatty acid found in the phospholipids of postprandial triglyceride-rich lipoproteins after a meal rich in olive oil, whereas stearic (18:0) and linoleic (18:2n-6) acids are those found with a meal rich in high-oleic sunflower oil and exhibit higher time of clearance. This metabolic process is also regulated by the nature of carried triglycerides, being more quickly removed $\mathrm{OOO}$ (triolein) followed by POO (palmitoyl-dioleoyl glycerol) and OOL (dioleoyl-linoleoyl glycerol) (Abia et al., 1999).

\section{ROLE OF APOLIPOPROTEINS AND RECEPTORS ON MECHANISMS INVOLVED IN POSTPRANDIAL LIPOPROTEINS CLEARANCE}

The mechanisms related to postprandial lipoproteins clearance are not well understood nowadays. The nascent $\mathrm{CM}$ are loaded with apo B-48. The nature of dietary fats modulates the expression of apo B-48. By using olive oil in a human model of postprandial metabolism, Abia et al. (2003) suggested that CM-phospholipids might interact with distinct cellular receptors to facilitate their incorporation. This agrees with the discovery of a novel and a uniquely receptor for apo B-48 in the human monocyte/macrophage line THP-1 and endothelial cells (Gianturco et al., 1999; Brown et al., 2000). It is of major importance for the knowledge of atherosclerosis development because macrophages loaded with triglyceride-rich lipoproteins, as oxidised-LDL, can turn on foam cells in the arterial intima (Gianturco et al., 1999). Apo B-48 receptor is a non-heparan sulphate-dependent dimmer (200 and $235 \mathrm{KDa}$ ) (Bradley et al., 1999). When heterologous expression of apo B-48 receptor is promoted in $\mathrm{CHO}$ cells, they become apparent as foam cells after incubation with triglyceride-rich lipoproteins (Brown et al., 2000; Brown et al., 2002). Unfortunately, we have no data on the effects of olive oil in the expression and activity of the receptor.

Apolipoproteins $\mathrm{E}$ are also involved in the clearance of lipoproteins. There are three main polymorphisms of apo E: E2, E3 and E4. E3 allele is present in $77 \%$ of the population and previous studies shown that correlates with plasma lipid profile. Over-expression of apo E3 in transgenic animals increases the level in plasma of total cholesterol and triglycerides. It appears that apo E3 leads to normolipemia, hypercholesterolemia or combined hyperlipidemia (hypercholesterolemia and hypertriglyceridemia) when expressed at low, medium or high levels, respectively (Tomkin et al., 2001). E4 allele is associated with high levels in plasma of LDL-cholesterol, whereas E2 allele prevents the postprandial increase of plasma triglycerides (Minihane et al., 2000) and the fasting levels of plasma cholesterol (Larson et al., 2000).

The importance of lipids supply for extra-hepatic tissues by CM during postprandial processes determines the existence of a protector mechanism from too rapid uptake by the liver. Apolipoprotein C-III interferes with apo $E$ binding sites at the receptors 
and inhibits the activity of apolipoprotein C-II, an activator of LPL. These apolipoproteins are not formed in the enterocytes, but are constituent of the high-density lipoproteins (HDL). MUFA-rich diets increase the content of apo $\mathrm{E}$ in postprandial triglyceride-rich lipoproteins (Madigan et al., 2000). It is not known whether olive oil can modify the apo C-III/apo C-II ratio.

\section{SECRETION OF LIPOPROTEINS BY THE LIVER}

The liver quickly metabolizes the postprandial remnant lipoproteins. Those of size smaller than 100 $\mathrm{nm}$ are up taken by hepatocytes in the space of Disse (Fraser et al, 1995). Larger triglyceride-rich lipoproteins re-circulate over the peripheral tissues. In the liver, triglycerides can be used for energy and cholesterol for the biosynthesis of membranes, conferring the optimal fluidity to their physiological functions. Throughout the postprandial metabolism, the liver secretes new triglyceride-rich lipoproteins (VLDL) to the blood circulation. This process occurs usually after 5-6 hours post-meal period (Abia et al., 1999).

MTP mediates the formation of VLDL in hepatocytes, by regulating triglyceride accumulation in the microsomal lumen and triglyceride assembly with apo B-100 (Kulinski et al., 2002). A deficiency in MTP causes abetalipoproteinemia, but up-regulation of MTP has been shown to increase the amount of triglycerides in VLDL (Liao et al., 1999). Nascent VLDL touch with small lipoproteins charged with apo $\mathrm{E}$ and apo C-II (HDL), activating LPL and HL. The size of VLDL diminishes and lipoproteins turn on intermediary-density lipoproteins (IDL) and finally on LDL, the remnant particle of VLDL. LDL contains large amounts of cholesterol and almost none of triglycerides (Chapell et al., 1998). Independently of its lipolytic activity, HL promotes the hepatic uptake of remnants and IDL particles (Perret et al., 2002; Zambon et al., 2003)

The expression and secretion of apo B-100 correlate with the pool of fatty acids in the hepatocytes. Particularly, oleic acid increases (29 $\%)$ the amount of apo B-100 in the medium of hepatoma cells, with no change in triglyceride synthesis (Arrol et al., 2000). VLDL particles secreted had lower density compared to other unsaturated fatty acids, such as linoleic, arachidonic (20:4n-6) and eicosapentaenoic (20:5n-3) acids, and SFA, such as lauric (12:0), myristic (14:0), palmitic (16:0) and arachidic (20:0) acids. All fatty acids, except stearic and a-linolenic $(18: 3 n-3)$ acids, were stimulators of apo $B$ and VLDL secretion. In addition, MUFA and PUFA were more potent than SFA.

The composition of VLDL may be modulated, at least partially, by the nature of triglycerides coming from the diet. In fact, it is well accepted that dietary fatty acids have influence at long-term on the fatty acid composition of cholesterol esters and phospholipids in LDL (Sarkkinen et al., 1994).

\section{METABOLIC EFFECTS OF OLIVE OIL}

Epidemiological studies suggest that consuming diets rich in (extra virgin) olive oil is associated with a low incidence of chronic disease, including cardiovascular disease and cancer. However, the effects of olive oil on health and disease cannot be understood without a profound understanding of how (extra virgin) olive oil components act at the cellular level.

The development of a diet-related disease involves a multitude of gene products, including proteins involved in lipid synthesis and oxidation, thermogenesis and cell differentiation. Nutrients we consume are among the most influential environmental factors that govern the expression of genes encoding these proteins. Nutrients govern the tissue content and activity of different proteins by functioning as regulators of gene transcription, nuclear RNA processing, mRNA degradation and mRNA translation, as well as functioning as post-translational modifiers of proteins.

The regulation of cell functions by fatty acids and minor compounds from (extra virgin) olive oil can occur on two general levels, modulation of signal transduction via manipulation of membrane fatty acid composition (non-genomic effect) and rapid and direct modification of gene transcription (genomic effect)

The initiation of gene transcription is a complex and tightly regulated process in which transcription factors, upon the appropriate stimuli, recognize and bind to specific DNA sequence motifs in the promoter region of the target gene. Upon this binding, mRNA for that particular gene is transcribed, and accumulation of its gene product begins. Transcription factors can be activated by phosphorylation, translocation of inactive complexes or synthesis de novo by other transcription factors.

\subsection{Non-genomic effects of olive oil}

Olive oil phenols interfere with leukotriene generation by inhibiting 5-lipoxygenase and 12-lipoxygenase activities in macrophages (Kohyama et al., 1997), but not cyclooxygenase (COX) activity. Therefore, their role in prostaglandin biosynthesis is due not only to their action on COX activity but also to their effects on COX levels. Reactive oxygen species (ROS) may be involved in the pathways that result in arachidonic acid mobilization from membranes and $\mathrm{PGE}_{2}$ release by COX-2. The tyrosol and $\beta$-sitosterol treatments that inhibit ROS production can prevent COX-2 expression induced by phorbol ester (PMA). 
However, tyrosol and $\beta$-sitosterol have no effect on COX-2 activity in a cell-free enzyme system from macrophages stimulated by PMA (Moreno, 2003). Taken together, these results are consistent with the hypothesis that tyrosol and $\beta$-sitosterol inhibit arachidonic acid cascade through ROS release modulation. This may result from the transcriptional or post-transcriptional regulation of mRNA stability, which remains to be established. The promoter region of the COX-2 gene contains several binding sites for transcriptional factors that may be regulated by the cellular redox state, like NF-kB (Zwacka et al., 1998). Thus, antioxidants like tyrosol and $\beta$-sitosterol may interfere with NF-kB. It confirms that both olive oil minor components reduce the NF- $\mathrm{kB}$ activation induced by PMA, whose interaction amplifies COX-2 promoter activation.

\subsection{Genomic effects of olive oil}

The following section will review transcription factors that play a role in diet-related diseases regulated by (extra virgin) olive oil components (Table 2).

\subsection{1. $N F-\kappa B$}

The transcription factor NF-kB complex is present in the cytoplasm as a heterodimer composed of NFKB1 (p50) and Rel a (p65) subunits bound to one of a number of inhibitory proteins called $1 \kappa B s$. In response to diverse stimuli, including inflammatory cytokines, mitogens and several viral proteins, sheer stress and oxidative processes, NF-kB dissociates from $\mathrm{lkB}$, the $\mathrm{p} 50 / \mathrm{p} 65$ complex translocates to the nucleus because of the complete proteolytic degradation of the $1 \kappa B$ proteins. NF-kB activation has been linked to the onset of atherosclerosis. It activates a variety of target genes that regulate cell proliferation and mediate cell survival as well as genes relevant to the pathophysiology of the vessel wall, including genes that regulate the expression of cytokines (interferon $\gamma$ and $\beta$, interleukin-3, interleukin-6, GM-CSF), chemokines, vaso-regulatory molecules (endothelial tissue factor, nitric oxide synthase), and leukocyte adhesion molecules (ICAM-1, ELAM-1, VCAM-1).

The effect of olive oil on proliferation, cytokine production and pleiotropic genes expression through NF- $\kappa \mathrm{B}$ activation has been considered beneficial or neutral by several authors (Rusyn et al., 1999; Verlengia et al., 2003). Thus, oleic acid does not stimulate induction of NF-kB and therefore does not activate endothelial cells (Henning et al., 2000; Massaro et al., 2002). However, the effect of oleic acid on NF- $\mathrm{kB}$ activation remains controversial. Recent studies have suggested that elevated levels of oleic and linoleic acids in plasma result in endothelial dysfunction, through an increase in

Table 2

Transcription factor pathways mediating nutrient-gene interaction

\begin{tabular}{|l|l|l|}
\hline $\begin{array}{l}\text { TRANSCRIPTION } \\
\text { FACTOR }\end{array}$ & \multicolumn{1}{|c|}{ COMPOUNDS } & $\begin{array}{c}\text { TARGET GENES } \\
\text { TRANSACTIVATED }\end{array}$ \\
\hline NF-kB & $\begin{array}{l}\text {-Oleic acid (activation, inhibition) } \\
\text {-Phenolics (oleuropein, hybroxytyrosol) } \\
\text { (inhibition) } \\
\text { - } \text { Icarotene (inhibition) } \\
\text {-Linoleic acid (activation) }\end{array}$ & $\begin{array}{l}\text { Inflammatory } \\
\text { cytokines, } \\
\text { chemokines, vaso- } \\
\text { regulatory molecules, } \\
\text { leukocyte adhesion } \\
\text { molecules, genes that } \\
\text { regulate cell } \\
\text { proliferation }\end{array}$ \\
\hline C-myc & $\begin{array}{l}\text {-Oleic and linoleic acids } \\
\text { - -3carotene } \\
\text {-aTocopherol (inhibition) } \\
\text { and B), apoptosis and } \\
\text { differentiation }\end{array}$ \\
\hline AP-1 & $\begin{array}{l}\text {-Oleic acid (inhibition) } \\
\text {-Linoleic and } \alpha \text {-linolenic acid (activation) } \\
\text {-Phenolics, Bcarotene, } \alpha \text {-tocopherol } \\
\text { (inhibition) }\end{array}$ & $\begin{array}{l}\text { Proliferation, p21, } \\
\text { apoptosis, p53, p19, } \\
\text { cytokines }\end{array}$ \\
\hline LXR & $\begin{array}{l}\text { Polyunsaturated>monounsaturated>saturated } \\
\text { fatty acids (pattern of inhibition) }\end{array}$ & $\begin{array}{l}\text { Genes for lipoprotein } \\
\text { lipase, sterol } \\
\text { regulatory-element- } \\
\text { binding protein 1c, } \\
\text { ATP-binding cassette } \\
\text { transporter Al }\end{array}$ \\
\hline PPARs & $\begin{array}{l}\text { Genes involved in } \\
\text { lipid and glucose } \\
\text { metabolism }\end{array}$ \\
\hline
\end{tabular}


endothelin-1 (Park et al., 2003) and vascular adhesion molecule-1 (VCAM-1) protein expression (Dichtl et al., 2002) via activation of protein kinase C and NF-kB.

Phenolics present in extra virgin olive oil, transcriptionally inhibit endothelial adhesion molecules expression by inhibiting NF- $\mathrm{kB}$ activation, partially explaining the vascular athero-protective effect of extra virgin olive oil (Massaro et al., 2002; Carluccio et al., 2003). Analysis of the NF-kB activation pathways reveals that the antioxidants do not inhibit activation of the $I_{\kappa B} B$ kinase activity, degradation of $I_{\kappa} B \alpha$, or translocation of activated $N F-\kappa B$ into the nucleus, but they do block the formation of p50/p65/DNA binding complexes (Ma et al., 2003).

It has been recently reported that $B$-carotene induces growth-inhibitory and pro-oxidant effects, and increases the DNA-binding activity of nuclear proteins at $\mathrm{NF}-\kappa \mathrm{B}$ site in leukemic and colon adenocarcinoma cells (Palozza et al., 2003). In these cells, treatment with $\alpha$-tocopherol supports the hypothesis that carotenoids regulate this transcription factor through a pro-oxidant mechanism. Other minor compounds from extra virgin olive oils have been shown to inhibit translocation of NF- $\mathrm{KB}$ and interrupt cardiac inflammatory cytokine secretion (Horton et al., 2001).

\subsection{2. $\quad c-M y c$}

A growing body of evidence indicates that c-Myc can play a pivotal role in both neoplasia and cardiovascular diseases. This protein product of cellular proto-oncogen c-myc is widely known as one of the essential transcription factors that perform cellular growth, proliferation, apoptosis, cell cycle entry and differentiation.

C-Myc is a sequence specific DNA binding protein that has a helix-loop-helix $(\mathrm{HLH})$ and a leucine zipper (Zip) for protein dimerization and a basic region (b) for DNA binding at its $\mathrm{C}$-terminal end. Heterodimerization of c-Myc with another $\mathrm{b} / \mathrm{HLH} / \mathrm{Zip}$ protein Max and binding of Myc-Max heterodimer to an E-box DNA motif [5-CA(C/T)GTC] is a prerequisite for the transcriptional regulation and activity of the c-Myc protein. C-Myc-Max also controls other transcription factors by sequestering or interacting with them, including activator protein (AP)-2 and elongation-2 factor, which are involved in the basal machinery of cell.

Some olive oil components may have anti-tumoral and anti-atherogenic effects by inhibiting c-Myc activation. Some studies have demonstrated that c-Myc activation is an early event in lipid accumulation within coronary arterial wall, occurring prior to development of atherosclerosis. MUFA and PUFA have strong inhibitory effects on the binding of the c-Myc-Max heterodimer to an E-box DNA site. The interaction with the protein dimmer, not with DNA, blocks the entire c-Myc-Max-DNA complex formation, causing anti-proliferative effects in human cancer cells (Chung et al., 2002). Similar to NF-kB, $\mathrm{c}-\mathrm{Myc}$ is a redox-sensitive transcription factor. C-Myc is a NF- $\kappa \mathrm{B}$ target gene and is implicated in apoptosis induction. Accordingly, B-carotene is able to increase the expression of $c-M y c$, which is directly related to apoptosis induction (Palozza et al., 2003). Some studies have demonstrated that $\alpha$-tocopherol is able to reduce the activation of c-Myc-dependent signalling pathways in coronary lesions of animals and humans (de Nigris et al., 2000; 2001).

\subsection{3. $A P-1$}

Activator protein-1 (AP-1) is a transcription factor composed of homodimeric or heterodimeric combinations of the transcription factor proteins Fos and Jun, which bind to a common DNA consensus site. The AP-1 consensus site is located in the promoters of many genes involved in inflammatory responses relevant to vascular pathophysiology, including basic fibroblast growth factor (bFGF), transforming growth factor $B$ (TGFB), endothelin-1 and plasminogen activator-1. AP-1 protein also affects cell growth and survival by their ability to transactivate the expression of genes that regulate the cell cycle.

The process of inflammation is now believed to be the etiological event that precedes the development and continual process of atherosclerosis. There is accumulating evidence that point out the beneficial influence of extra virgin olive oil in the immune function (Yaqoob et al., 1998; Adam et al., 2000; Miles et al., 2001). PUFA, such as linoleic acid and to a lesser extent $\alpha$-linolenic acid, can contribute to induction of inflammatory genes in vascular endothelial cells via AP-1 activation. However, oleic acid seems to have no effect or down-regulate the activity of AP-1, resulting in a decreased inflammatory gene mRNA (Toborek et al., 2002; Viswanathat et al., 2003). Thus, the high ratio of MUFA to PUFA found in olive oil may contribute to its substantial benefit in cardiovascular diseases.

Phenolics from extra virgin olive oil at nutritionally relevant concentrations transcriptionally inhibit endothelial adhesion molecular expression via inhibition of AP-1 (Carluccio et al., 2003). Further studies have provided molecular evidence supporting the beneficial effect of $\alpha$-tocopherol in the development of inflammation via suppression of IL-4 expression by blocking binding of transcription factors to IL-4 promoter binding sites for AP-1 (Li-Weber et al., 2002). B-Carotene is also an effective inhibitor of breast cancer, possibly mediated through down-regulation of cell cycle regulatory 
proteins and/or inhibition of AP-1 transcriptional activity (Tibaduiza et al., 2002).

\subsubsection{Nuclear receptors}

Nuclear receptors are one of the largest groups of transcription factors, with 49 distinct members presently identified in the human genome. Nuclear receptors are regulators integrating different homeostatic controls:

- Energy and glucose metabolism [peroxisome proliferators-activated receptor gamma (PPAR $\lambda$ )].

- Fatty acid, triglyceride and lipoprotein metabolism (PPAR $\alpha, B / \delta$ and $\gamma$ ).

- Reverse cholesterol transport and cholesterol absortion [liver $X$ receptors (LXR) and liver receptor homolog-1 (LRH-1)].

- Bile acid metabolism [farnesol $X$ receptor (FXR), LXR, LRH-1].

- Defence against xeno- and endobiotics [pregnane X, receptor/steroid and xenobiotic receptor (PXR/SXR)].

Nuclear receptors have a modular structure characterized by a ligand-independent AF-1 transactivation domain in the $\mathrm{N}$-terminal region, a highly conserved DNA-binding domain composed of two zinc fingers recognizing specific DNA sequences, and a ligand-binding and dimerization domain that contains a ligand-dependent AF-2 transactivation domain in its C-terminal portion. Most nuclear receptors are active as dimmers with the retinoid X receptor (RXR, NR2B1) and bind to specific nucleotide sequences (response element) in the promoter region of a large number of genes. During ligand binding, nuclear receptors undergo a conformational change that results in the coordinated dissociation of co-repressors and the recruitment of co-activator proteins to enable transcriptional activation (Francis et al., 2003).

In the past few years, it has become clear that fatty acids induce or inhibit the mRNA expression of a variety of different genes by acting both, as agonist and as antagonists for nuclear hormone receptors. The present section briefly reviews recent data on the mechanisms by which fatty acids influence DNA transcription and focus especially on the importance of two nuclear receptors, LXR and PPARs.

LXR is believed to act as a sterol sensor in cells up-regulating genes involved in cholesterol elimination when cells are faced with excess sterol. LXR forms obligate heterodimers with RXR, which then enhance the transcription of such genes as those for LPL, SREBP-1c (sterol regulatory-element-binding protein 1 c) and $A B C$ sterol transporters, such as $A B C A 1$ (ATP-binding cassette transporter A1, a sterol transporter critical for facilitating the cholesterol and phospholipids to lipid-poor apolipoproteins, resulting in the formation of nascent HDL particles). Two different LXR genes have been described, LXR $\alpha$ and $L X R ß$. Fatty acids induce $L X R \alpha$ gene expression in the liver (Tobin et al., 2000) and activate LXR $\alpha$ transcription factor in the intestine (Murthy et al., 2004). Furthermore, these studies have postulated that SREBP-1c and ABCA1 are gene targets of LXR through fatty acid activation, suggesting an important cross-talk between fatty acids metabolism and cholesterol regulation. The pattern of inhibition clearly favours unsaturated fatty acids over SFA and, in most studies, PUFA over MUFA (Hannah et al., 2001; Ou et al., 2001). Thus, PUFA but not oleic acid decrease both LXR-mediated SREBP-1c mass and gene expression (Field et al., 2002). Murthy et al. (2004) have recently shown that fatty acids decrease the efflux of cholesterol in Caco-2 cells in response to LXR activation, without changing (by linoleic and stearic acids) or modestly attenuating [by oleic, arachidonic and docosahexaenoic (22:6n-3) acids] ABCA1 gene expression. Except for oleic acid, all fatty acids substantially attenuated an increase in ABCA1 mass secondary to LXR activation. The authors suggested that oleic acid probably decreases cholesterol efflux by diverting cholesterol away from ABCA1 towards ACAT (acylCoA:cholesterol acyltransferase). This fact would indicate that diets enriched in oleic acid would preferentially promote intestinal cholesterol secretion in triglyceride-rich lipoproteins and less cholesterol secretion in nascent HDL.

In addition, it has become clear that induction of gene transcription by fatty acids is often mediated by PPARs. PPAR $\alpha$ is mostly expressed in brown adipose tissue and liver; PPARß/ $\delta$ is present at high concentrations in numerous tissues but it is especially abundant in the intestine; PPAR $\gamma$ is most abundant in white adipose tissue and to a lesser extent in colon and macrophages. Some authors have provided support for an anti-atherogenic role of PPAR $\gamma$ (Chawla et al., 2001; Chinetti et al., 2001). PUFA, as well as MUFA and SFA, induce the expression of reporter genes in a PPAR-dependent manner. Although most fatty acids including SFA and unsaturated fatty acids bind PPARs with low to moderate affinity, it is not entirely clear whether their relative affinities differ greatly. In general, all isoforms of PPARs are more responsive to 18-22 carbon $n-6$ and $n$-3 PUFA than to MUFA and SFA. According to Xu et al. (1999), SFA and MUFA bind to the PPAR subtype with approximately equal affinity. The highest binding affinity was found for linoleic acid.

\section{METABOLISM AND EXCRETION OF OLIVE OIL MINOR COMPOUNDS}

Studies on phenolics metabolism show differences between administered doses and excreted metabolic products in urine. It is unknown 
whether the remaining fraction is evacuated with the faeces without be absorbed, destroyed in the gut, or accumulated in organs or circulating cells, such as erythrocytes. The quantities of phenolic compounds found intact in urine vary from one to another. The low recovery for some of them is not explained by chemical degradation in the gut, as they have shown a great stability in gastric or intestinal juices (Olthof et al., 2001).

Intestinal absorption of phenolic compounds can be high; however, the plasma concentration of any individual molecule rarely exceeds $1 \mu \mathrm{M}$ after the consumption of $10-100 \mathrm{mg}$ of a single compound. The plasma antioxidant capacity suggests that more phenolics should be present, mainly in the form of metabolites generated by either tissues or colonic microflora (Scalbert et al., 2000). It is assumed that dietary doses, contrary to drug doses, do not readily saturate the metabolic pathways and hence circulating species would be expected to be conjugated (Bell et al., 2000). The dose will also determine the primary site of metabolism. Large doses are metabolised primarily in the liver, whereas small doses are rather metabolised by the intestinal mucosa, with the liver playing a secondary role to modify conjugates from the small intestine (Piskula et al., 1998).

In the colon, the microflora can also hydrolyse flavonoid glucuronides excreted in the bile and the resulting aglycone reabsorbed, thus entering into an entero-hepatic cycle (Aura et al., 2002). Aglycones can also further be metabolised to a wide variety of low molecular weight aromatic acids (phenylvaleric, phenylpropionic, phenylacetic and benzoic acids), which are well absorbed through the colonic barrier (Deprez et al., 2000). The amount of substrates reaching the colon and the tissue exposure to their microbial metabolites could be highest than the amount of the absorbed phenolic compounds (Scalbert et al., 2002).

The metabolism of phenolic compounds implies reactions of conjugation on aglycones, after the hydrolysis of phenol derivatives is produced. Major conjugation reactions include the formation of o-glucuronides (Spencer et al., 1999; Donovan et al., 2001), sulphate esters and o-methyl ethers (Manna et al., 2000). They occur firstly in the gut and then in plasma facilitating its urinary and biliary excretion (Scalbert et al., 2002). The formation of phenol conjugates can dramatically alter the biological properties of the circulating metabolites.

Miro-Casas et al. (2001) quantified the amount of excreted tyrosol in urine, reporting a maximal concentration in the first $4 \mathrm{~h}$ after (extra virgin) olive oil ingestion. Total urine recoveries were about $25 \%$ of the ingested tyrosol, in which $6-11 \%$ consisted of free tyrosol and the remaining as glucuronide conjugates. Vissers et al. (2001) estimated the human absorption of a phenol-rich supplement obtained from (extra virgin) olive oil, finding the net absorption $>55 \mathrm{~mol} / 100 \mathrm{~mol}$ and the re-excretion of tyrosol and hydroxytyrosol 5-16 mol/100 mol.

Hydroxytyrosol and tyrosol are excreted in urine as glucuronide conjugates with a positive correlation between the amounts of phenolics ingested and glucuronide conjugation of urine metabolites (Visioli et al., 2000). Other metabolites of hydroxytyrosol [homovanillic acid (4-hydroxy-3-methoxy phenylacetic acid) and homovanillic alcohol] in humans (Caruso et al., 2001), and oxidised and methylated derivatives of hydroxytyrosol (3,4-dihydroxyphenilacetic acid; 3,4-dihydroxyphenylacetaldehyde; and sulfoconjugated derivatives) (D'Angelo et al., 2001) in animals were later detected. Figure 1 shows different metabolites of hydroxytyrosol including enzymatic pathways of formation.

Recently, it has been determined hydroxytyrosol and 3-o-methyl-hydroxytyrosol in plasma after real-life doses of extra virgin olive oil (Miro-Casas et al., 2003), finding that approximately $98 \%$ of hydroxytyrosol appears to be present in plasma and urine in glucuronide-conjugated forms, which suggests extensive first-pass intestinal/hepatic metabolism of the ingested hydroxytyrosol.

Into the enterocytes, B-carotene can be converted to vitamin $A$. This process is highly regulated, and consequently toxic levels of vitamin $A$ from ingested carotenoids are rare (Olson, 1994). Carotenoids distribute into lipoproteins (LDL) where they exert antioxidant activities, and in tissues, mainly adipose tissue (85\%), liver (12\%) and muscle $(3 \%)$. Particularly, lutein has been shown to suffer oxidative modifications in human serum, forming metabolites with anti-tumoral activities (Khachik et al., 1995). In further studies, Khachik et al. (1997) identified dehydrated metabolites of lutein.

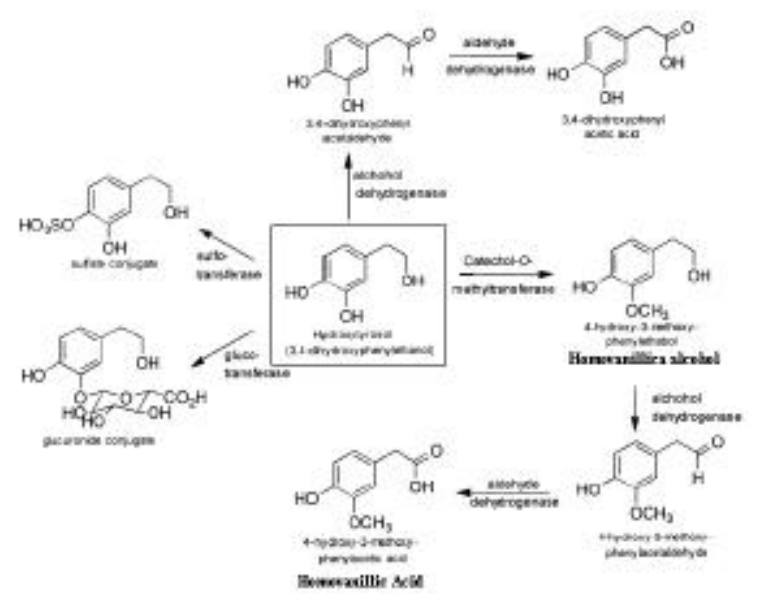

Figure 1

Metabolites from hydroxytyrosol (adapted from Tuck et al., 2002). 
Tocopherols are metabolised in the liver, by a pathway involving cytochrome P450-mediated $\omega$-hydroxylation of the phytyl side chain followed by stepwise removal of two- or three-carbon moieties, ultimately yielding the 3-carboxychromanol metabolite that is excreted in urine (Sontang and Parker, 2002). The $\alpha$-tocopherol transfer protein $(\alpha$-TTP) specifically binds $\alpha$-tocopherol and sorts it out for incorporation into plasma lipoproteins (Schuelke et al., 2000), what suggests a high regulation of the plasma and tissue levels of $\alpha$-tocopherol. That is in accordance to the fact that only a-tocopherol, among other tocopherols, has signalling functions in vascular smooth muscle cells (Brigelius-Flohe and Traber, 1999; Azzi et al., 2000). The metabolic pathway of the hepatic degradation of $\alpha$-tocopherol has not been fully established, but $\omega$ and B-oxidations probably occur after $\omega$-hydroxylation, suggesting the participation of a CYP3A-type cytochrome (Birringer et al., 2001). Furthermore, the same authors pointed out that a competition of microsomal $\omega$-oxidation with specific binding by the $\alpha$-TTP could determine the metabolic fate of tocopherols.

Finally, some of these metabolites are recently probed to have effects on cancer cell proliferation, by specific down-regulation of cyclin expression (Galli et al., 2004). The presence of vitamin E metabolites in plasma is parallel to the ingested parent compounds, as have been assessed by high performance liquid chromatography (Lodge et al., 2001; Radosavac et al., 2002) and gas-chromatography/mass spectrometry (Galli et al., 2002 ).

\section{ACKNOWLEDGMENTS}

The authors would like to acknowledge to the Ministry of Education and Science (ECl) of the Spanish Government for supporting this manuscript (grant AGL2001-0584). Beatriz Bermúdez and Sergio López are supported by I3P and FPU fellowships, whereas Yolanda M. Pacheco has an I3P Post-Doctoral contract from ECl.

\section{REFERENCES}

Abia, R., Perona, J.S., Pacheco, Y.M., Montero E., Muriana, F.J.G., Ruiz-Gutierrez, V. (1999). Postprandial triacylglycerols from dietary virgin olive oil are selectively cleared in humans. J. Nutr., 129, 2184-2191.

Abia, R., Pacheco, Y.M., Montero, E., Ruiz-Gutierrez, V., Muriana, F.J.G. (2003). Distribution of fatty acids from dietary oils into phospholipids classes of triacylglycerol-rich lipoproteins in healthy subjects. Life Sci., 72, 1643-1656.

Adam, J.M., Raju, J., Khalil, N., Bird, R.P (2000). Evidence for the involvement of dietary lipids on the modulation of transforming growth factor-beta1 in the platelets of male rats. Mol. Cell. Biochem., 211, 145-152.

Aoe, S., Yamamura, J., Matsuyama, H., Hase, M., Shiota, M., Miura, S. (1997). The positional distribution of dioleoyl-palmitoyl glycerol influences lymph chylomicron transport, composition and size in rats. $J$. Nutr., 127, 1269-1273.

Arrol, S., Mackness, M.I., Durrington, P.N. (2000). The effects of fatty acids on apolipoprotein $B$ secretion by human hepatoma cells (HEP G2). Atherosclerosis, 150, 255-264.

Aura, A.M., O'Leary, K.A., Williamson, G., Ojala, M., Bailey, M., Puupponen-Pimia, R. (2002). Quercetin derivatives are deconjugated and converted to hydroxyphenylacetic acids but not methylated by human fecal flora in vitro. J. Agric. Food Chem., 50, 1725-1730.

Azzi, A.M., Breyer, I., Feher, M., Pastori, M., Ricciarelli, R., Spycher, S., Staffieri, M., Stocker, A., Zimmer, S., Zingg, J.M. (2000). Specific cellular responses to alpha-tocopherol. J. Nutr., 130, 1649-1652.

Bell, J.R.C., Donovan, J.L., Wong, R., Waterhouse, A.L. German, J.B., Walzem, R.L., Kasim-Karakas, S.E. (2000). (+)-Cathechin in human plasma after ingestion of a single serving of reconstituted red wine. Am. J. Clin. Nutr., 71, 103-108.

Birringer, M., Drogan, D., Brigelius-Flohe, R., (2001). Tocopherols are metabolised in HepG2 cells by side chain omega-oxidation and consecutive betaoxidation. Free Radic. Biol. Med., 31, 226-232.

Bradley, W.A., Brown, M.L., Ramprasad, M.P., Li, R., Song, R., Gianturco, S.H. (1999). Antipeptide antibodies reveal interrelationships of MBP 200 and MBP 235: unique apoB-specific receptors for triglyceride-rich lipoproteins on human monocyte-macrophages. J. Lipid. Res., 40, 744-752.

Brigelius-Flohe, R., Traber, M.G. (1999). Vitamin E: function and metabolism. FASEB. J., 13, 1145-1155.

Brown, M.L., Ramprasad, M.P., Umeda, P.K., Tanaka, A., Kobayashi, Y., Watanabe, T., Shimoyamada, H., Kuo, W.L., Li, R., Song, R., Bradley, W.A., Gianturco, S.H. (2000). A macrophage receptor for apolipoprotein B48: Cloning, expression, and atherosclerosis. Proc. Natl. Acad. Sci., 97, 7488-7493.

Brown, M.L., Yui, K., Smith, J.D., LeBoeuf R.C., Weng, W., Umeda, P.K., Li, R., Song, R., Gianturco, S.H., Bradley, W.A. (2002). The murine macrophage apoB-48 receptor gene (Apob-48r): homology to the human receptor. J. Lipid. Res., 43, 1181-1191.

Carluccio, M.A., Siculella, L., Ancora, M.A., Massaro, M., Scoditti, E., Storelli, C., Visioli, F., Distante, A., De Caterina, R. (2003). Olive oil and red wine antioxidant polyphenols inhibit endothelial activation: antiatherogenic properties of Mediterranean diet phytochemicals. Arterioscler. Thromb. Vasc. Biol., 23, 622-629.

Caruso, D., Visioli, F., Patelli, C., Galli, C., Galli, G. (2001). Urinary excretion of olive oil phenols and their metabolites in humans. Metabolism, 50, 1426-1428.

Chapell, D.A., Medh, J.D. (1998). Receptor-Mediated Mechanisms of Lipoprotein Remnant Catabolism. Prog. Lipid. Res., 37, 393-422.

Chawla, A., Boisvert, W.A., Lee, C.H., Laffitte, B.A., Barak, Y., Joseph, S.B., Liao, D., Nagy, L., Edwards, P.A., Curtiss, L.K., Evans, R.M., Tontonoz, P. (2001). A PPAR gamma-LXR-ABCA1 pathway in macrophages is involved in cholesterol efflux and atherogenesis. Mol. Cell., 7, 161-171.

Chinetti, G., Lestavel, S., Bocher, V., Remaley, A.T., Neve, B., Torra, I.P., Teissier, E., Minnich, A., Jaye, M., Duverger, N., Brewer, H.B., Fruchart, J.C., Clavey, V., Staels, B. (2001). PPAR-alpha and PPAR-gamma activators induce cholesterol removal from human 
macrophage foam cells through stimulation of the ABCA1 pathway. Nat. Med., 7, 53-58.

Chung, B.H., Hennig, B., Simon Cho, B.H., Darnell, B.E. (1998). Effect of the fat composition of a single meal on the composition and cytotoxic potencies of lipolytically release free fatty acids in postprandial plasma. Atherosclerosis, 141, 321-332.

Chung, S., Park, S., Yang, C.H. (2002). Unsaturated fatty acids bind Myc-Max transcription factor and inhibit Myc-Max-DNA complex formation. Cancer Lett., 188, 153-162.

DAngelo, S., Manna, C., Migliardi, V., Mazzoni, P., Morrica, G., Capasso, G., Pontoni, G., Galleti, P., Zappia, V. (2001). Pharmacokinetics and metabolism of hydroxytyrosol, a natural antioxidant from olive oil. Drug. Metab. Dispo., 29, 1492-1498.

De Nigris, F., Youssef, T., Ciafre, S., Franconi, F., Anania, V., Condorelli, G., Palinski, W., Napoli, C. (2000). Evidence for oxidative activation of c-Myc-dependent nuclear signaling in human coronary smooth muscle cells and in early lesions of Watanabe heritable hyperlipidemic rabbits: protective effects of vitamin E. Circulation, 102, 2111-2117.

De Nigris, F., Lerman, L.O., Rodriguez-Porcel, M., De Montis, M.P., Lerman, A., Napoli, C. (2001). c-myc activation in early coronary lesions in experimental hypercholesterolemia. Biochem. Biophys. Res. Commun., 281, 945-950.

Déprez, S., Brézillon, C., Rabot, S., Philippe, C., Mila, I., Lapierre, C., Scalbert, A. (2000). Polymeric proanthocyanidins are catabolized by a human colonic microflora into low molecular weight phenolic acids. J. Nutr., 130, 2733-2738.

Dichtl, W., Ares, M.P., Jonson, A.N., Jovinge, S., Pachinger, O., Giachelli, C.M., Hamsten, A., Eriksson, P., Nilsson, J. (2002). Linoleic acid-stimulated vascular adhesion molecule- 1 expression in endothelial cells depends on nuclear factor-kappaB activation. Metabolism, 51, 327-333.

Donovan, J.L., Crespy, V., Manach, C., Morand, C., Besson, C., Scalbert, A., Remesy, C. (2001). Catechin is metabolized by both the small intestine and liver of rats. J. Nutr., 131, 1753-1757.

Francis, G.A., Fayard, E., Picard, F., Auwerx, J. (2003) Nuclear receptors and the control of metabolism. Annu. Rev. Physiol., 65, 261-311.

Fraser, R., Dobbs, B.R., Rogers, G.W.T. (1995). Lipoproteins and the liver sieve: the role of the fenestrated sinusoidal endothelium in lipoprotein metabolism, atherosclerosis and cirrhosis. Hepatology, 21, 863-874.

Field, F.J., Born, E., Murthy, S., Mathur, S.N. (2002). Polyunsaturated fatty acids decrease the expression of sterol regulatory element-binding protein-1 in CaCo-2 cells: effect on fatty acid synthesis and triacylglycerol transport. Biochem. J., 368, 855-864.

Galli, F., Lee, R., Dunster, C., Kelly, F.J. (2002). Gas chromatography mass spectrometry analysis of carboxyethyl-hydroxychroman metabolites of alphaand gamma-tocopherol in human plasma. Free Radic. Biol. Med., 32, 333-340.

Galli, F., Stabile, A.M., Betti, M., Conte, C., Pistilli, A., Rende, M., Floridi, A., Azzi, A. (2004). The effect of alpha- and gamma-tocopherol and their carboxyethyl hydroxychroman metabolites on prostate cancer cell proliferation. Arch. Biochem. Biophys., 423, 97-102.

Gianturco, S.H., Bradley, W.A. (1999). Pathophysiology of triglyceride-rich lipoproteins in atherotrombosis: Cellular aspects. Clin. Cardiol., 22, II7-II14.
Hannah, V.C., Ou, J., Luong, A., Goldstein, J.L., Brown, M.S. (2001). Unsaturated fatty acids down-regulate srebp isoforms $1 \mathrm{a}$ and $1 \mathrm{c}$ by two mechanisms in HEK-293 cells. J. Biol. Chem., 276, 4365-4372.

Heeren, J., Niemeier, A., Merkel, M., Beisigel, U. (2002). Endothelial-derived lipoprotein lipase is bound to postprandial triglyceride-rich lipoproteins and mediates their hepatic clearance in vivo. J. Mol. Med., 80, 576-584.

Hennig, B., Meerarani, P., Ramadass, P., Watkins, B.A., Toborek, M. (2000). Fatty acid-mediated activation of vascular endothelial cells. Metabolism, 49, 1006-1013.

Higashi, K., Ishikawa, T., Shige, H., Tomiyasu, K., Yoshida, H., Ito, T., Nakajima, K., Yonemura, A., Sawada, S., Nakamura, H. (1997). Olive Oil increases the magnitude of postprandial chylomicron remnants compared to milk fat and safflower oil. J. Am. Coll. Nutr., 16, 429-434.

Horton, J.W., White, D.J., Maass, D.L., Hybki, D.P., Haudek, S., Giroir, B. (2001). Antioxidant vitamin therapy alters burn trauma-mediated cardiac NF-kappaB activation and cardiomyocyte cytokine secretion. J. Traumatol., 50, 397-406.

Innearity, T.L., Boren, J., Yamanaka, S.I., Olofsson, S.O. (1999). Biosynthesis of apolipoprotein B48-containing lipoproteins. Regulation by novel post-transcriptional mechanism. J. Biol. Chem., 271, 2353-2356.

Jackson, K.G., Robertson, M.D., Fielding, B.A., Frayn, K.N., Williams, C.M. (2002). Olive Oil increases the number of triacylglycerol-rich chylomicron particles compared with others oils: an effect retained when a second standard meal is fed. Am. J. Clin. Nutr., 76, 942-949.

Khachik, K., Beecher, G., Smith, J.C. (1995). Lutein, lycopene and their oxidative metabolites in chemoprotection of cancer. J. Cell. Biochem., 22, 236-224.

Khachik, K., Spangler, C.J., Smith, J.C., Canfield, L.M., Steck, A., Pfander, H. (1997). Identification, quantification and relative concentrations of carotenoids and their metabolites in human milk, and serum. Anal.Chem., 69, 1873-1881.

Kohyama, N., Nagata, T., Fujimoto, S., Sekiya K. (1997). Inhibition of arachidonate lipoxygenase activities by 2-(3,4-dihydroxyphenyl)ethanol, a phenolic compound from olives. Biosci. Biotechnol. Biochem., 61, 347-350.

Kulinski, A., Rustaeus, S., Vance, J.E. (2002). Microsomal triacylglycerol transfer protein is required for lumenal accretion of triacylglycerol not associated with $A p o B$, as well as for ApoB Lipidation. J. Biol. Chem., 35, 31516-31525.

Larson, I.A., Ordovas, J.M., DeLuca, C., Barnard, J.R., Feussner, G., Schaefer, E.J. (2000). Association of apolipoprotein (Apo)E genotype with plasma apo $E$ levels. Atherosclerosis, 148, 327-336.

Liao, W., Kobayashi, K., Chan, L. (1999). Adenovirus-mediated overexpression of microsomal triglyceride transfer protein (MTP): mechanistic studies on the role of MTP in apolipoprotein B-100 biogenesis. Biochemistry, 38, 7532-7544.

Li-Weber, M., Giaisi, M., Treiber, M.K., Krammer, P.H. (2002). Vitamin E inhibits IL-4 gene expression in peripheral blood T cells. Eur. J. Immunol., 32 , 2401-2408.

Lodge, J.K., Ridlington, J., Leonard, S., Vaule, H., Traber, M.G. (2001). Alpha- and gamma-tocotrienols are metabolised to carboxyethyl-hydroxychroman derivatives and excreted in human urine. Lipids, 36 , 43-48. 
Luchoomun, J., Hussain, M.M. (1999). Assembly and secretion of chylomicrons by differentiated Caco-2 cells. Nascent triglycerides and preformed phospholipids are preferentially used for lipoprotein assembly. J. Biol. Chem., 274, 19565-19572.

Ma, Q., Kinner, K., Ye, J., CChen, B.J. (2003). Inhibition of nuclear factor $\mathrm{kB}$ phenolic antioxidants: Interplay between antioxidants signalling and inflammatory cytokine expression. Mol. Pharmacol., 64, 211-219.

Madigan, C., Ryan, M., Owens, D., Collins, P., Johnson, A., Tomkin, G.H. (2000). Effect of a diet rich in monounsaturated fatty acids on the apolipoproteins involved in the clearance of postprandial lipoproteins in type 2 diabetic patients. Diabetologia, 43, A38.

Manna, C., Galletti, P., Maisto, G., Cucciolla, V., DAngelo, S., Zappia, V. (2000). Transport mechanism and metabolism of olive oil hydroxytyrosol in Caco-2 cells. FEBS Lett., 470, 341-344.

Massaro, M., Carluccio, M.A., Paolicchi, A., Bosetti, F., Solaini, G., De Caterina, R. (2002). Mechanisms for reduction of endothelial activation by oleate: inhibition of nuclear factor-kappaB through antioxidant effects. Prostaglandins Leukot. Essent. Fatty Acids, 67, 175-181.

Mekki, N., Charbonnier, M., Borel, P., Leonardi, J., Juhel, C., Portugal, H., Lairon, D. (2002). Butter differs from olive oil and sunflower oil in its effects on postprandial lipemia and triacylglycerol-rich lipoproteins after single mixed meals in healthy young men. J. Nutr., 132, 3642-3649.

Miles, E.A., Wallace, F.A., Calder, P.C. (2001). An olive oil-rich diet reduces scavenger receptor mRNA in murine macrophages. Br. J. Nutr., 85, 185-191.

Minihane, A.M., Khan, S., Leigh-Firbank, E.C., Talmud, P., Wright, J.W., Murphy, M.C., Griffin, B.A., Williams, C.M. (2000). ApoE polymorphism and fish oil supplementation in subjects with an atherogenic lipoprotein phenotype. Arterioscler. Thromb. Vasc. Biol., 20, 1990-1997.

Miro-Casas, E., Albadalego, M.F., Covas, M.I., Rodrigues, F.O., Colomer, E.M., Raventos, R.M.L., de la Torre Fornell, R. (2001). Capillary gas-chromatographymass spectrometry quantitative determination of hydroxytyrosol and tyrosol in human urine after olive oil intake. Anal. Biochem., 294, 63-72.

Miro-Casas, E., Covas, M.I., Farre, M., Fito, M., Ortuño, J., Weinbrenner, T., Roset, P., de la Torre, R.. (2003). Hydroxytyrosol disposition in humans. Clin. Chem., 49, 945-952.

Moreno, J.J. (2003). Effect of olive oil minor components on oxidative stress and arachidonic acid mobilization and metabolism by macrophages RAW 264.7. Free Radic. Biol. Med., 35, 1073-1081.

$\mathrm{Mu}, \mathrm{H}$. , Hoy, C.E. (2004). The digestion of dietary triacylglycerols. Prog. Lipid Res., 43, 105-133.

Murthy, S., Born, E., Mathur, S.N., Field, F.J. (2004). Liver-X-receptor-mediated increase in ATP-binding cassette transporter $A 1$ expression is attenuated by fatty acids in CaCo-2 cells: effect on cholesterol efflux to high-density lipoprotein. Biochem. J., 377, 545-552.

Olson, J.A. (1994). Absorption, transport, and metabolism of carotenoids in humans. Pure App. Chem., 66, 1011-1016.

Olthof, M.R., Hollman, P.C.H., Katan, M.B. (2001). Chlorogenic acid and caffeic acid are absorbed in humans. J. Nutr., 131, 66-71.

Ou, J., Tu, H., Shan, B., Luk, A., DeBose-Boyd, R.A., Bashmakov, Y., Goldstein, J.L., Brown, M.S. (2001). Unsaturated fatty acids inhibit transcription of the sterol regulatory element-binding protein-1c (SREBP-1c) gene by antagonizing ligand-dependent activation of the LXR. Proc. Natl. Acad. Sci., 98, 6027-6032.

Palozza, P., Serini, S., Torsello, A., Di Nicuolo, F., Piccioni, E., Ubaldi, V., Pioli, C., Wolf, F.I., Calviello, G. (2003) Beta-carotene regulates NF-kappaB DNA-binding activity by a redox mechanism in human leukemia and colon adenocarcinoma cells. J. Nutr., 133, 381-388.

Park, Y., Harris, W.S. (2003). Omega-3 fatty acid supplementation accelerates chylomicron triglyceride clearance. J. Lipid. Res., 44, 455-463.

Perret, B., Mabile, L., Martinez, L., Terce, F., Barbares, R., Collet, X. (2002). Hepatic lipase: structure/function relationship, synthesis and regulation. J. Lipid. Res., 43, 1163-1169.

Piskula, M.K., Terao, J. (1998). Accumulation of (-)-Epicatechin metabolites in rat plasma after oral administration and distribution of conjugation enzymes in rat tissues. J. Nutr., 128, 1172-1178.

Radosavac, D., Graf, P., Polidori, M.C., Sies, H., Stahl, W. (2002). Tocopherol metabolitos 2, 5, 7, 8-tetramethyl2-(2carboxyethyl)-6-hydroxychroman (alpha-CEHC) and 2, 7, 8-trimethyl-2-(2carboxyethyl)-6-hydroxychroman (gamma-CEHC) in human serum after a single dose of natural vitamin E. Eur. J. Nutr., 41, 119-124.

Rusyn, I., Bradham, C.A., Cohn, L., Schoonhoven, R., Swenberg, J.A., Brenner, D.A., Thurman, R.G. (1999). Corn oil rapidly activates nuclear factor-kappaB in hepatic Kupffer cells by oxidant-dependent mechanisms. Carcinogenesis, 20, 2095-2100.

Sakr, S.W., Haourigui, M., Paul, J.L., Soni, T., Vachter, D., Girard-Globa, A. (1997). Fatty acid composition of an oral fat load affects chylomicron size in human subjects. Br. J. Nutr., 77, 19-31.

Sarkkinen, E.S., Agren, J.J., Ahola, I., Ovaskainen, M.L., Uusitupa, M.I. (1994). Fatty acid composition of serum cholesterol esters, and erythrocyte and platelet membranes as indicators of long-term adherence to fat-modified diets. Am. J. Clin. Nutr., 59, 364-370.

Scalbert, A., Williamson, G. (2000). Dietary intake and bioavailability of polyphenols. J. Nutr., 130, 2073S-2085S.

Scalbert, A., Morand, C., Manach, C., Remesy, C. (2002). Absorption and metabolism of polyphenols in the gut and impact on health. Biomed. Pharmacother., 56, 276-282.

Shiau, Y.F., Popper, D.A., Reed, M., Umstetter, C., Capuzzi, D., Levine, G.M. (1985). Intestinal triglycerides are derived from both endogenous and exogenous sources. Am. J. Physiol., 248, 164-G169.

Schuelke, M., Elsner, A., Finckh, B., Kohlschutter, A., Hubner, C., Brigelius-Flohe, R. (2000). Urinary alpha-tocopherol metabolites in alpha-tocopherol transfer protein-eficient patients. J. Lipid. Res., 41, 1543-1551.

Sontag, T.J., Parker, R.S. (2002). Cytochrome P450 omega-hydroxylase pathway of tocopherol catabolism. Novel mechanism of regulation of vitamin $E$ status. $J$. Biol. Chem., 277, 25290-25296.

Spencer, J.P., Chowrimootoo, G., Choudhury, R., Debnam, E.S., Srai, S.K., Rice-Evans, C. (1999). The small intestine can both absorb and glucuronidate luminal flavonoids. FEBS Lett., 458, 224-230.

Sultan, F., Langrange, D., Jansen, H., Griglio, S. (1990). Inhibition of hepatic lipase activity impairs chylomicron remnant removal in rats. Biochim. Biophys. Acta, 1042, 150-152.

Tibaduiza, E.C., Fleet, J.C., Russell, R.M., Krinsky, N.I. (2002). Excentric cleavage products of beta-carotene 
inhibit estrogen receptor positive and negative breast tumor cell growth in vitro and inhibit activator protein-1-mediated transcriptional activation. J. Nutr., 132, 1368-1375.

Toborek, M., Lee, Y.W., Garrido, R., Kaiser, S., Hennig, B. (2002). Unsaturated fatty acids selectively induce an inflammatory environment in human endothelial cells. Am. J.Clin. Nutr., 75, 119-125.

Tobin, K.A., Steineger, H.H., Alberti, S., Spydevold, O. Auwerx, J., Gustafsson, J.A., Nebb, H.I. (2000). Cross-talk between fatty acid and cholesterol metabolism mediated by liver $\mathrm{X}$ receptor-alpha. Mol. Endocrinol., 14, 741-752.

Tomkin, G.H., Owens, D. (2001). Abnormalities in apoB-containing lipoproteins in diabetes and atherosclerosis. Diabetes Metab. Res. Rev., 17, 27-43.

Tuck, K.L., Hayball, P.J. (2002). Major phenolic compounds in olive oil: metabolism and health effects. J. Nutr. Biochem., 13, 636-644

Van Greevenbroek, M.M.J., Van Meer, G., Erkelens, D.W., De Bruin, J.W.A. (1996). Effects of saturated, mono-, and polyunsaturated fatty acids on the secretion of apo B containing lipoproteins by Caco-2 cells. Atherosclerosis, 121, 139-150.

Van Greevenbroek, M.M.J., de Bruin, T.W.A. (1998a). Chylomicron synthesis by intestinal cells in vitro and in vivo. Atherosclerosis, 141, S9-S16.

Van Greevenbroek, M.M.J., Robertus-Teunissen, M.G., Erkelens, D.W., de Bruin, J.W.A. (1998b). Lipoprotein secretion by intestinal Caco-2 cells is affected differently by trans and cis unsaturated fatty acids: effect of carbon chain length and position of the double bond. Am. J. Clin. Nutr., 68, 561-567.

Van Greevenbroek, M.M.J., Robertus-Teunissen, M.G., Erkelens, D.W., de Bruin, J.W.A., (1998c). Participation of the microsomal triglyceride transfer protein in lipoprotein assembly in Caco-2 cells: interaction with saturated and unsaturated fatty acids. J. Lipid. Res., 39, 173-185.
Verlengia, R., Gorjao, R., Kanunfre, C.C., Bordin, S., de Lima, T.M., Curi, R. (2003). Effect of arachidonic acid on proliferation, cytokines production and pleiotropic genes expression in Jurkat cells--a comparison with oleic acid. Life. Sci., 73, 2939-2951.

Visioli, F., Galli, C., Bornet, F., Mattei, A., Patelli, R., Galli, G., Caruso, D. (2000). Olive oil phenolics are dose-dependently absorbed in humans. FEBS. Lett., 468, 159-160.

Vissers, M.N., Zock, P.L., Wiseman, S.A., Meyboom, S., Katan, M.B. (2001). Effect of phenol-rich extra virgin olive oil on markers of oxidation in healthy volunteers. Eur. J. Clin. Nutr., 55, 334-341.

Viswanathan, S., Hammock, B.D., Newman, J.W., Meerarani, P., Toborek, M., Hennig, B. (2003). Involvement of CYP 2C9 in mediating the proinflammatory effects of linoleic acid in vascular endothelial cells. J. Am. Coll. Nutr., 22, 502-510.

Yaqoob, P., Knapper, J.A., Webb, D.H., Williams, C.M., Newsholme, E.A., Calder, P.C. (1998). Effect of olive oil on immune function in middle-aged men. Am. J. Clin. Nutr., 67, 129-135.

Xiang, S.Q., Cianflone, K., Kalant, D., Sniderman, A.D. (1999). Differential binding of triglyceride-rich lipoproteins to lipoprotein lipase. J. Lipid Res., 40, 1655-1663.

Xu, H.E., Lambert, M.H., Montana, V.G., Parks, D.J., Blanchard, S.G., Brown, P.J., Sternbach, D.D., Lehmann, J.M., Wisely, G.B., Willson, T.M., Kliewer, S.A., Milburn M,V. (1999) Molecular recognition of fatty acids by peroxisome proliferator-activated receptors. Mol. Cell, 3, 397-403.

Zwacka, R.M., Zhou, W., Zhang, Y., Darby, C.J., Dudus, L., Halldorson, J., Oberley, L., Engelhardt, J.F. (1998). Redox gene therapy for ischemia/reperfusion injury of the liver reduces AP1 and NF-kappaB activation. Nat. Med., 4, 698-704.

Zambon, A., Bertocco, S., Vitturi, N., Polentarutti, V., Vianello, D., Crepaldi, G. (2003). Relevance of hepatic lipase to the metabolism of triacylglycerol-rich lipoproteins. Biochem. Soc. Trans., 31, 1070-1074. 